\title{
A Methocarbamol Combination to Prevent Toxicity of Non-steroidal Anti Inflammatory Drugs
}

\author{
Seung-Min Yeom ${ }^{1,2}$, Min-Seok Kim ${ }^{1,3}$, Eric Lingenfelter ${ }^{1,4}$, Jonathan Broadwell ${ }^{5}$ \\ ${ }^{1}$ USFK, Army 2nd Infantry Division, Camp Hovey Combined Troops Medical Aid Station, Dongducheon, Korea \\ ${ }^{2}$ College of Pharmacy, Woo-suk University, Jeonju, Korea \\ ${ }^{3}$ College of Nursing, Chung-Ang University, Seoul, Korea \\ ${ }^{4}$ Defense Health Agency, Washington, USA \\ ${ }^{5}$ Army National Guard, University of Utah School of Medicine, Salt Lake, USA
}

\section{비스테로이드성 항염증제의 약물독성 예방을 위한 Methocarbamol의 약물조합}

\author{
염승민 ${ }^{1,2}$, 김민석 ${ }^{1,3}$, Eric Lingenfelter ${ }^{1,4}$, Jonathan Broadwell $^{5}$ \\ ${ }^{1}$ 주한미군 육군 제 2 보병사단 캠프호비 클리닉, ${ }^{2}$ 우석대학교 약학대학, ${ }^{3}$ 중앙대학교 간호대학, ${ }^{4}$ 미국 국방보건국, ${ }^{5}$ 미국 주방위군, 유타대학교 의과대학
}

\begin{abstract}
To prevent toxicity from both robax platinum (methocarbamol, ibuprofen) and robaxacet (methocarbomol, acetaminophen), separately, we used stretches and naproxen as a non-steroidal anti-inflammatory drug (NSAID) to compare each effectiveness. This study used the United States Forces Korea Prescription form (Annex A-Over-The-Counter Prescription) and Alice Rich's Pain scale with robax platinum, robaxacet including narproxen. The IBM SPSS statics version 24 was used to calculate the data. The combined methocarbamol $500 \mathrm{mg}$, acetaminophen $325 \mathrm{mg}$ tablet, and ibuprofen $200 \mathrm{mg}$ (or naproxen) tablet can work as well as the combined methocarbamol 500 mg tablet with acetaminophen $325 \mathrm{mg}$ tablet with stretches. Both methods were successful in managing pain. The drug combination of methocarbamol $500 \mathrm{mg}$, acetaminophen $325 \mathrm{mg}$ and ibuprofen $200 \mathrm{mg}$ tablets yielded similar benefits as the methocarbamol $500 \mathrm{mg}$ and acetaminophen $325 \mathrm{mg}$ tablets paired with physical stretching exercises regarding managing overall pain.
\end{abstract}

Key words: Methocarbamol, NSAID, Stretches, Toxicity

This is an Open Access article distributed under the terms of the Creative Commons Attribution Non-Commercial License (http://creativecommons.org/licenses/by-nc/4.0) which permits unrestricted non-commercial use, distribution, and reproduction in any medium, provided the original work is properly cited.

Copyright @ 2017 The Korean Society for Clinical Laboratory Science. All rights reserved.
Corresponding author: Seung-Min Yeom USFK, Army 2nd Infantry Division, Camp Hovey Combined Troops Medical Aid Station, 2557 Pyeonghwa-ro, Dongducheon 11311, Korea Tel: 82-31-298-7655

Fax: 82-31-298-7656

E-mail: smyeom@yonsei.ac.kr

Received: March 14, 2017 Revised 1 $1^{\text {st: }}$ April 4, 2017 Revised $2^{\text {nd }}$ : April 4, 2017 Revised $3^{\text {rd. }}$ : April 14, 2017 Revised $4^{\text {th: }}$ : April 16, 2017 Revised $5^{\text {th }}$ : April 16, 2017 Accepted: April 17, 2017

\section{INTRODUCTION}

The patients on the professional athletic background such as military service members are directly exposed to musculoskeletal disorders. In case of muscle pain, the more various pains occur, the more personalized medicine treatments are needed because of each patient has certain underlying diseases such as gastrointestinal, cardiovascular and any specific others. As part of personalized medicine, targeted treatment is necessary as one of the important ways to alleviate pain. To avoid overdose and prevent each toxicity, various types of pain treatments such as 
additional exercise should be considered to treat them. If patients take amount of over the counter, they could possibly be overdosage. As part of targeted treatment, the following results are considered to be one of the important ways to study toxicity. According to the following stack plot of nuclear magnetic resonance spectra (NMR) (Figure 1), the targeted experiment showing characteristics of metabolic fingerprints with tissue-specific toxicity produced by different site-selective toxicity such as xenobiotics. It was given in single doses to rats in relation to an untreated control. In this case, by using $600-\mathrm{MHz}$ which most precise frequency to investigate specific chemical resonance result from metabolic pathway on NMR test, each 600-MHz spectrum represents one time point after dosing for each toxic compound [1]. It can show the toxicity on xenobiotics relatively affect specific regions within the organs (depicted in the figure by shaded boxes): puromycin affects the renal glomeruli; uranyl nitrate affects the lower regions of proximal tubules and others such as result that 2-bromoethanamine affects renal medulla, including loop of Henle and collecting ducts; and hydrazine affects hepatic parenchymal cells $[1,2]$. Therefore, it's necessary to treat patients based on patient's underlying diseases.

In case of another chemical tracking [3], we could see

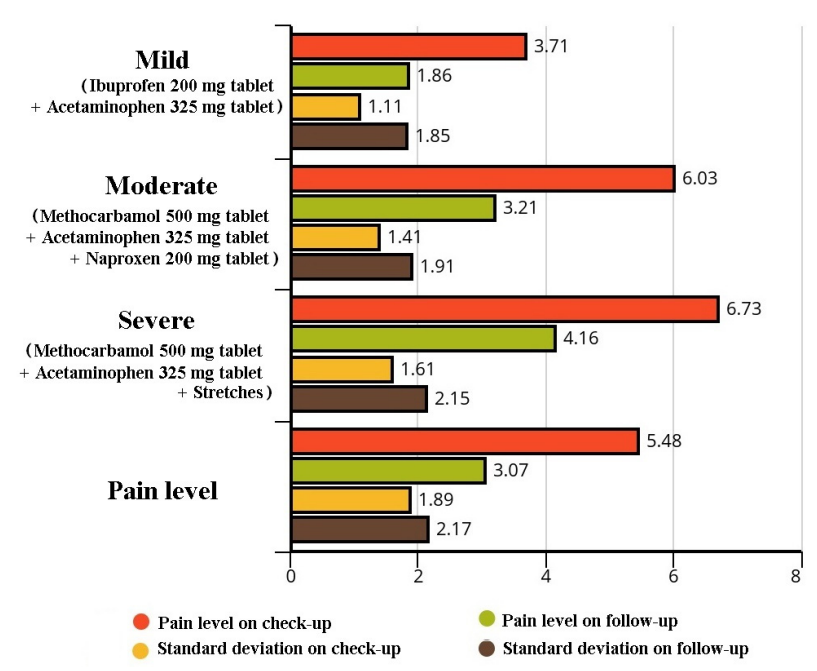

Figure 1. The result of pain reliefs combination with each methocarbamol, acetaminophen, naproxen or ibuprofen and stretch. the dose-dependent perturbations in urinary metabolite concentrations caused by naproxen toxicity. These were investigated by using ${ }^{1} \mathrm{H}$ NMR spectroscopy coupled with multivariate statistical analysis [3]. Histopathologic evaluation of naproxen-induced acute gastrointestinal damage in rats demonstrated a significant dose-dependent effect. Furthermore, principal component analysis $(\mathrm{PCA})$ of ${ }^{1} \mathrm{H}$ NMR from rat urine revealed a dose-dependent metabolic shift between the vehicle-treated control rats and rats treated with low-dose (10 mg/kg body weight), moderate-dose $(50 \mathrm{mg} / \mathrm{kg})$, and high-dose $(100 \mathrm{mg} / \mathrm{kg})$ naproxen, coinciding with their gastric damage scores after naproxen administration [3]. The resultant metabolic profiles demonstrate that the naproxen-induced gastric damage exhibited energy metabolism perturbations that elevated their urinary levels of citrate, cis-aconitate, creatine, and creatine phosphate. These findings demonstrate that ${ }^{1} \mathrm{H}$ NMR-based urinary metabolic profiling can facilitate noninvasive and rapid diagnosis of drug side effects and is suitable for elucidating possible biological pathways perturbed by drug toxicity [3-6].

Therefore, As part of personalized medicine, targeted treatment is necessary as various types of pain treatments. For instance, prescription including stretches can be used to treat patients are at risk of over dosage. Not only prescribed drugs but also over the counter drugs have to be considered in case of treatment for patients who have a various musculoskeletal pains on individual underlying diseases for a long term. According to previous study about hydrocodone with ibuprofen [7], it can show analgesic combination can be much effective than single analgesic.

\section{MATERIALS AND METHODS}

\section{Pain scale}

To measure the pain, we used Alice Rich's '0 10 Comparative Pain Scale' [8].

\section{Examed term}

In this study, the following record was performed on Declaration of Helsinki. All 90 patients who visited the 
United States Army Camp Hovey clinic from June 14, 2016 to September 23, 2016, with muscle pain including back pain. The patients were divided into two groups according to the level of pain and severity. The numerical value was calculated from mild, moderate, severe based on 0 to 10.

This exam is officially confidential information and got authorized to record on system and research associated with 'Declaration of Helsinki'. The researchers properly dealt with pain reliefs.

\section{NSAIDs and Methocarbamol, Acetaminophen}

This study used the United States Forces Korea Prescription form (Annex A-Over-The-Counter prescription) with robax platinum, robaxacet and naproxen including paracetamol and ibuprofen.

\section{Making pain relief combination based on metabolic pathways}

Methocarbamol is the carbamate of guaifenesin, but does not produce guaifenesin as a metabolite, because the carbamate bond is not hydrolyzed metabolically; metabolism is by Phase I ring hydroxylation and O-demethylation, followed by Phase II conjugation. All the major metabolites are unhydrolyzed carbamates [9,10].

Acetaminophen (paracetamol) is metabolised primarily in the liver, into toxic and non-toxic products. Three metabolic pathways are notable according to research of Prescott [10]. Glucuronidation ( $45 \sim 55 \%$ ) by UGT1A1 and UGT1A6, Sulfation (sulfate conjugation) (20 30\%) by SULT1A1 [11], N-hydroxylation and dehydration, then glutathione conjugation, (less than 15\%). The hepatic cytochrome $\mathrm{P} 450$ enzyme system metabolises paracetamol (mainly CYP2E1), forming a minor yet significant alkylating metabolite known as NAPQI (N-acetyl-p-benzoquinone imine) (also known as $\mathrm{N}$-acetylimidoquinone) [12]. Ibuprofen on primary metabolism is oxidative and involves the cytochrome P450 enzymes [13]. The hydroxy and carboxy metabolites of ibuprofen have no apparent pharmacological activity according to research of Davies NM [14]. In case of acetaminophen on primary metabolism is and toxicity, subsequently, the reactive metabolite of acetaminophen was identified to be N-acetyl-p-benzoquinone imine (NAPQI). It was found to be formed by cytochrome P-450 (CYP) by a direct two electron oxidation of acetaminophen, a previously unrecognized mechanism of CYP [15]. The CYP isoforms important in acetaminophen metabolism have been shown to be CYP2E1, CYP1A2, CYP3A4, and CYP2D6 [16]. Acetaminophen activation by human liver cytochromes P450IIE1 and P450IA2 [17] and covalent binding of acetaminophen to protein was found to correlate with P450IA2 [17], acetaminophen-induced hepatotoxicity [18].

Therefore, above data can show none of them is overlap with acetaminophen, naproxen (or ibuprofen) and methocarbamol. So we combined each group selectively to group1, 2 and 3. Each group indicate certain combination such as following. The group 1 received acetaminophen $325 \mathrm{mg}$ tablets ( 2 pills, $8 \mathrm{hr} \times 7$ days)+ibuprofen $200 \mathrm{mg}$ tablets (1 pill, $8 \mathrm{hr} \times 7$ days). The group 2 received acetaminophen $325 \mathrm{mg}$ tablets (2 pills, $8 \mathrm{hr} \times 7$ days)+methocarbamol $500 \mathrm{mg}$ tablets ( 1 pill, $8 \mathrm{hr} \times 2$ days)+naproxen or ibuprofen $200 \mathrm{mg}$ (1 pill, $8 \mathrm{hr} \times 7$ days). The group 3 received acetaminophen $325 \mathrm{mg}$ tablet (2 pills, $8 \mathrm{hr} \times 7$ days $)+$ methocarbamol $500 \mathrm{mg}(1 \mathrm{pill}, 8 \mathrm{hr} \times 2$ days)+stretches ( 3 times a day, every $8 \mathrm{hr} \times 7$ days).

\section{Dosage}

According to the U.S. Food and Drug Administration (FDA) and various research [19] taking too much acetaminophen can damage your liver. The recommended maximum daily dose is 4,000 mg per day for adults. However, the difference between a safe dose of acetaminophen and one that may harm the liver is very small. In severe cases, an overdose of acetaminophen can cause liver failure or death.

Adult oral dose of acetaminophen for pain [20], Immediate-release: $325 \mathrm{mg}$ to $1 \mathrm{~g}$ orally every 4 to 6 hours, maximum single dose: $1000 \mathrm{mg}$, maximum dose per day: $4 \mathrm{~g}$ per $24 \mathrm{hr}$. For the management of mild to moderate pain and the management of moderate to severe pain with adjunctive opioid analgesics [20]. According to previous research [20], even though it shows possibility to be mixed 
with any other analgesics, it can also has possibility to be toxicity. That's the reason why we setup the stretch instead of additional analgesics more than methocarbamol and NSAIDs such as naproxen and ibuprofen. But we prescribed $1.9 \mathrm{~g}$ (acetaminophen 2 pills, $8 \mathrm{hr} \times 7$ days) to each patient to less dosage. It's against overdose and can make it realize to monitor each patient for 14 days without possible toxicity. According to above information, we used $47.5 \%$ of maximum dose.

Adult oral dose of NSAIDs such as naproxen and ibuprofen for pain [21], the immediate release (naproxen sodium) is $550 \mathrm{mg}$ orally once, followed by $275 \mathrm{mg}$ orally every 6 to $8 \mathrm{hr}$ or $550 \mathrm{mg}$ orally every $12 \mathrm{hr}$ as needed. The maximum dose is $1375 \mathrm{mg} /$ day initial total daily dose; thereafter, not to exceed $1,100 \mathrm{mg} /$ day. We prescribed $600 \mathrm{mg}$ a day (1 pill, $8 \mathrm{hr} \times 7$ days) to less the dosage. It's against overdose and can make it be monitored for 14 days without possible toxicity According to above information, we used $43.6 \%$ of maximum dose.

Administration of methocarbamol for adults is the Initial dosage and 3 tablets four times a day [22]. The maintenance dosage is 2 tablets four times a day. In case of $750 \mathrm{mg}$ methocarbamol, Adults have to 2 tablets four times a day on Initial dosage. In case of maintenance dosage, 1 tablet every four hours or 2 tablets three times a day. So, 6 grams a day are comprehensively recommended for the first 48 to 72 hours of treatment. But we prescribed 1.5 grams (methocarbamol $500 \mathrm{mg}, 1$ pill, $8 \mathrm{hrs}$ ) a day to less the dosage against overdose. Because we had to monitor and track each patient for 14 days. According to above information, we used $25 \%$ of maximum dose and much less than maximum dose because methocarbamol is prescribed analgesic and have CNS problem if someone overdose this analgesic [23].

According to both of administration and the United States Forces Korea Prescription form (Annex A-Over-The-Counter Prescription), we properly controlled dosage as much as we strictly. It can be against toxicity to prove alternative stretch can act as well as analgesic. Therefore, the biggest difference with drug and toxic compound is dosage. It can be checked in following clinical result.
Beside previous research about metabolic pathway with NMR [1], we can also investigate and track the each analgesic with immunoassays to detect adducts in the blood samples of patients with acetaminophen overdose [24]. It's including a number of the fundamental reason why we prevent the overdose because these previous methods show why overdose is harmful and stressful to each organ in case of overdose. Therefore, we setup stretch as an alternative rehabilitation to avoid overdose about analgesic and decrease the stress to each organ

\section{Stretches in case of group 3}

We used stretches to compare combination which including methocarbamol and NSAID. They were separated into 3 groups and used stretches which republished from Pierre Rouzier's the sports medicine patient advisor 3rd edition. Beside prescribing more NSAIDs, to setup the stretch as a mild placebo, we prescribe stretches for each patient to avoid overdose. We necessarily prescribe stretch instead of adding more NSAIDs to prevent the overdose. So we were expecting positive reaction on stretch as a mild placebo as well.

\section{Making experimental group}

In group 1, 2 and 3, group 1 was given acetaminophen $325 \mathrm{mg}$ tablet and Ibuprofen $200 \mathrm{mg}$ tablet when the pain scale was light and the range of motion was normal. The 90 patients were separated into 3 groups by using the pain scale. The showed a range of motion and muscle movement limitation (limited movement) and both of them showed a level of severity.

\section{Research analysis}

Patients who have musculoskeletal disease are separated into group 1, group 2 and group 3 based on pain level such as mild, moderate and severe each. The group 1 received acetaminophen $325 \mathrm{mg}$ tablets ( 2 pills, $8 \mathrm{hr} \times 7$ days)+ibuprofen $200 \mathrm{mg}$ tablets ( 1 pill, $8 \mathrm{hr} \times 7$ days). The group 2 received acetaminophen $325 \mathrm{mg}$ tablets ( 2 pills, $8 \mathrm{hr} \times 7$ days)+methocarbamol $500 \mathrm{mg}$ tablets (1 pill, $8 \mathrm{hr} \times 2$ days)+naproxen or ibuprofen $200 \mathrm{mg}$ tablets (1 pill, 8 
$\mathrm{hr} \times 7$ days). The group 3 received acetaminophen $325 \mathrm{mg}$ tablet ( 2 pills, $8 \mathrm{hr} \times 7$ days $)+$ methocarbamol $500 \mathrm{mg}(1$ pill, $8 \mathrm{hr} \times 2$ days) + stretches ( 3 times a day, every $8 \mathrm{hr} \times 7$ days). Patients who underwent concurrent drug treatment were subjected to a normality test based on declaration of Helsinki properly.

\section{Statics}

Repeat measurement variance analysis was performed with the IBM SPSS statics 24 program. A total of 90 patients with musculoskeletal disease were divided into 3 groups of 30 patients each, and the treatment methods were also divided into group 1, group 2, and group 3. Then, we repeated measurement variance analysis. It was performed on the data of the patients who had received the initial exam and the patients who had received the exam two weeks later as follow-up. Box was tested for identity.

\section{RESULTS}

All 90 of patients were evenly separated into 30 patients each to prevent various errors and control the experimental groups. Each group depended on patient's answer and pain scale level such as mild, moderate and severe level. The group 1 (who have mild pain) received acetaminophen

Table 1. Estimated average around

\begin{tabular}{cccc}
\hline \multirow{2}{*}{ Time } & Mean (SE) & \multicolumn{2}{c}{$95 \%$ Confidence interval } \\
\cline { 2 - 3 } & & Lowest limit & Highest limit \\
\hline Check-up & $5.48(0.14)$ & 5.19 & 5.78 \\
Follow-up & $3.07(0.20)$ & 2.66 & 3.49 \\
\hline
\end{tabular}

Abbreviation: SE, standard error.
$325 \mathrm{mg}$ tablets ( 2 pills, $8 \mathrm{hr} \times 7$ days)+ibuprofen $200 \mathrm{mg}$ tablets ( 1 pill, $8 \mathrm{hr} \times 7$ days). We were tracking the pain progress on group 1. After 2 weeks from check-up, this group 1's combination alleviated the pain level from average 3.71 to average 1.86. The SD (standard deviation)s of group 1's pain level were 1.11 and 1.86 on check-up and on follow-up each according to (Figure 1) and (Table 1).

The group 2 (who have moderate pain) received acetaminophen $325 \mathrm{mg}$ tablets (2 pills, $8 \mathrm{hr} \times 7$ days)+methocarbamol $500 \mathrm{mg}$ tablets (1 pill, $8 \mathrm{hr} \times 2$ days)+naproxen or Ibuprofen $200 \mathrm{mg}$ (1 pill, $8 \mathrm{hr} \times 7$ days). We were also tracking the pain progress on group 2 . After 2 weeks from check-up, this meds combination alleviated pain level from average 3.71 to average 1.86 . The SDs of group 2's pain level were 1.40 and 1.91 on check-up and on follow-up each.

The group 3 (who have severe pain) received acetaminophen $325 \mathrm{mg}$ tablet ( 2 pills, $8 \mathrm{hr} \times 7$ days $)+$ methocarbamol $500 \mathrm{mg}$ (1 pill, $8 \mathrm{hr} \times 2$ days)+stretches ( 3 times a day, every $8 \mathrm{hr} \times 7$ days). We were also tracking the pain progress on group 3. After 2 weeks from check-up, this meds combination alleviated pain level from average 3.71 to average 1.86. The SDs of group 3's pain level were 1.61 and 2.15 on check-up and on follow-up each.

In the second place Table 2 shows pain level progress based on each combination. Before a check (Table 2), Table 3 should be reffered. Table 3 is investigated to prove each medication combination is discreetly made based on independent drug pathway.

Overall, we can compare this result with previous research [26] by using comparison. In case of any selective COX 2 inhibitor versus naproxen, these can be compared

Table 2. Pain level progress based on each combination

\begin{tabular}{|c|c|c|c|c|c|c|c|c|}
\hline \multirow{2}{*}{ Group } & \multirow{2}{*}{$\mathrm{N}$} & \multicolumn{2}{|c|}{ Check-up } & \multicolumn{2}{|c|}{ Follow-up } & \multicolumn{3}{|c|}{ Values } \\
\hline & & Mean & SD & Mean & SD & $\mathrm{T}$ & $\mathrm{F}$ & $p$ \\
\hline $1($ Acet+lbu) & 30 & 3.71 & 1.11 & 1.86 & 1.85 & 4.67 & 58 & $<0.05$ \\
\hline $2($ Acet+Met+lbu) & 30 & 6.03 & 1.40 & 3.20 & 1.91 & 6.53 & 58 & $<0.05$ \\
\hline 3 (Acet+Met+Str) & 30 & 6.73 & 1.61 & 4.16 & 2.15 & 5.22 & 58 & $<0.05$ \\
\hline
\end{tabular}

Abbreviation: N, number of patients; SD, standard deviation; Acet, acetaminophen $325 \mathrm{mg}$ tablet (2 pills, every $8 \mathrm{hr} \times 7$ days); Ibu, ibuprofen $200 \mathrm{mg}$ tablet ( 1 pill, $8 \mathrm{hr} \times 7$ days); Met, methocarbamol $500 \mathrm{mg}$ tablet ( 1 pill, every $8 \mathrm{hr} \times 2$ days); nap, naproxen $500 \mathrm{mg}$ tablet ( 1 pill, every $8 \mathrm{hr} \times 7$ days); str, stretches ( 3 times a day, every $8 \mathrm{hr} \times 7$ days); Err, standard error of difference; T, t-test; F, degree of freedom; $p$, probability value. 
with naproxen, allocation to a selective COX 2 inhibitor [26]. It was associated with a highly significant increase in the incidence of a vascular event (rate ratio 1.57, 1.21 to 2.03; $p<0.05$ ) and a twofold increased risk of a myocardial infarction (2.04, 1.41 to 2.96; $p<0.05$ ) according to [25].

Following (Table 3) shows selective COX 2 inhibitor versus placebo, subdivided by individual selective COX 2 inhibitor, for each of the primary outcomes [25]. Overall, among 121 placebo controlled trials, 216 vascular events occurred during 18,490 person years of exposure to a selective COX 2 inhibitor (1.2\%/year) compared with 112 during 12,639 person years of placebo (0.9\%/year), corresponding to a $42 \%$ proportional increase in the incidence of a first serious vascular event (rate ratio) [25]. According to (Table 3), we can check this significant result on COX 2 inhibitor pathway, also figure out the reason why a number of NSAIDs which are in charge of pain reliefs have to be selectively prescribed to avoid the toxicity on each organ. Because NSAIDs usually have COX 2 inhibitor metabolic pathway like above results.

If we see the heterogeneity among five drugs, we can check: $\chi^{2}=10.2, \mathrm{df}=1, p<0.05$. These are meaning each COX 2 inhibitor significantly has heterogeneity each. and then if we see the rate ratio, rate ratio is 1.41 and $95 \%$ confidence interval is from 1.13 to 1.78 and $p<0.05$ which meaning significant result about vascular events than placebo [26]. It can show selective COX 2 inhibitors are associated with a moderate increase in the risk of vascular events, as are high dose regimens of ibuprofen and diclofenac and high dose naproxen is not highly associated with such an excess [25]. According to this research and previous research [25], we could compare each other and figure out how to treat the patients who are sensitive at NSAIDs by using the alternative pain control such as a rehabilitation stretches comprehensively.

Basically, all groups were separated into each mild, moderate or severe group according to Alice Rich's standard. So the severity of each patient depended on patient's their own answer from the one of answers such as mild, moderate and severe. Therefore, that we can comprehensively figure out the pain levels are separated in order. If we see the (Table 1), we can check the mean of pain level of group 1 is 3.70 . The mean of pain level of group 2 is 6.03 and the mean of pain level of group 3 is 6.73 in order.

Each group has 30 patients each: $\mathrm{N}=30$. All $p$-values of Table 2 are significant because of all $p$-values are less than 0.05. So, by conventional criteria, these differences are considered to be extremely and statistically significant. All degrees of freedom (F) are same cause of controlled patient's number of each group. Mild group, group 1 had a least effect as pain reliefs combination cause of $\mathrm{T}$ : meaning value of t-test=4.67. We guess the reason is group 1 only used fundamental medicine such as acetaminophen and ibuprofen.

In confidence interval, the mean of mild group, group 1 's equals was 1.83 . The $95 \%$ confidence interval of this difference was from 1.04 to 2.62. Moderate group, group 2 is a most efficient pain reliefs combination. In confidence interval, the mean of group 2's equals was 2.83. The 95\% confidence interval of this difference was from 2.02 to 3.64. In confidence interval, the mean of group 3's equals

Table 3. Vascular events with placebo

\begin{tabular}{lccc}
\hline \multirow{2}{*}{ COX 2 inhibitor } & No of trials (Placebo) & Events/person years \\
\cline { 3 - 4 } & & Allocated COX 2 Inhibitor & Allocated NSAID \\
\hline Refecoxib & 37 & $98 / 6,638$ & $72 / 6,415$ \\
Celecoxib & 41 & $84 / 8,976$ & $29 / 4,953$ \\
Etoricoxib & 17 & $7 / 753$ & $2 / 414$ \\
Lumiracoxib & 12 & $14 / 1,375$ & $3 / 584$ \\
Valdecoxib & 14 & $13 / 748$ & $3 / 273$ \\
Subtotal & 121 & $216 / 18,490(1.2 \% /$ year) & $112 / 12,639(0.9 \% /$ year $)$ \\
Values & & Heterogeneity among five drugs: $\chi^{2}=10.2, \mathrm{df}=1, p<0.05$ \\
Rate ratio & 1.42, 95\% confidence interval 1.13 to $1.78, p<0.05$
\end{tabular}


was 2.56 . The $95 \%$ confidence interval of this difference is from 1.58 to 3.55. All groups are performed according to check-up and follow-up each other.

As a result, intermediate values used in calculations of group 1 are $\mathrm{t}=4.64, \mathrm{df}=58$, standard error of difference $=0.39$. In case of intermediate values used in calculations of group 2 are $\mathrm{t}=6.98, \mathrm{df}=58$, standard error of difference $=0.40$. In case of intermediate values used in calculations of group 3 are $t=5.22, \mathrm{df}=58$, standard error of difference $=0.49$. That is meaning the group 2 which used methocarbamol 500 mg, acetaminophen $325 \mathrm{mg}$, ibuprofen (or naproxen) 200 mg tablet is most effective combined pain relief in these 3 groups. Therefore, according to each t value, we can guess group 3 combination is most effective combination as a pain relief. And we can check no drugs are overlapped on each metabolic pathway to comprehensively stimulate vascular system and organs. That's also meaning each compounds can work properly without overdose on each organ. Relatively, the group 1 received less and weaker drugs such as acetaminophen $325 \mathrm{mg}$ tablets (2 pills, 8 $\mathrm{hr} \times 7$ days)+ibuprofen $200 \mathrm{mg}$ tablets ( 1 pill, $8 \mathrm{hr} \times 7$ days) than the group 2 and 3 . The group 2 received acetaminophen $325 \mathrm{mg}$ tablets ( 2 pills, $8 \mathrm{hr} \times 7$ days)+methocarbamol 500 mg tablets ( 1 pill, $8 \mathrm{hr} \times 2$ days)+naproxen or ibuprofen $200 \mathrm{mg}$ tablets ( 1 pill, $8 \mathrm{hr} \times 7$ days). But the biggest thing we have to focus on is group 3. Even though it received acetaminophen $325 \mathrm{mg}$ tablet ( 2 pills, $8 \mathrm{hr} \times 7$ days)+methocarbamol $500 \mathrm{mg}$ ( 1 pill, $8 \mathrm{hr} \times 2$ day)+stretches (3 times a day, every $8 \mathrm{hr} \times 7$ days).

Although group 3 (acetaminophen 325 mg+methocarbamol $500 \mathrm{mg}+$ stretches) has fewer drug combinations than group 2 (acetaminophen $325 \mathrm{mg}+$ methocarbamol $500 \mathrm{mg}+$ naproxen or ibuprofen $200 \mathrm{mg}$ ) and has two drug combinations like group 1 (acetaminophen $325 \mathrm{mg}+\mathrm{ibu}-$ profen $200 \mathrm{mg}$ ), group $3(\mathrm{t}=5.22)$ was better as pain relief than group 1 ( $\mathrm{t}=4.64)$ because it includes stretching we guess. And, the severe pain in group $3(\mathrm{t}=5.22)$ was alleviated as well as group $2(\mathrm{t}=6.98)$ can even though group 3 didn't work as same as group 2. In case of stretch, stretch for pain is distributed as alternative treatment. So stretch or exercise can release the pain [22] but has limitation to treat the pain dramatically. It's just used as a preventive way to avoid toxicity for someone who taking a same pain relief for a while just in case. In other words, to alleviate the severe pain, alternative treatment such as a stretch can be the alternative way to control the severe pain.

To extract an exact result based on physical mechanism as much as we can, we comprehensively compared metabolism of mechanism to double check whether this applying pain reliefs combination to human body is properly performed or not. It can be corresponded to what we referred in introduction. In (Figure 2), it is precisely showing how toxicity of each compound is processed according to previous research so far [1]. For instance, in case of first metabolic pathway, puromycin amino-nucleoside induces glomerular epithelial cell apoptosis [4]. In case of second direction, uranyl nitrate-induced acute renal failure in the rat: micropuncture and renal hemodynamic studies on research of Flamenbaum W [5]. In case of third direction, 2-bromoethanamine, 2-Bromoethylamine as a potent selective suicide inhibitor for semi-carbazide-sensitive amine oxidase [6]. It can also show why each compound can possibly induce stress of each organ on metabolic pathway. The control represent the mammalian nephron to comparatively track which components can be show up on the NMR testing in each organ and to compare with each toxicity base on fundamental amino acid and others such as glycine, alanine, valine, lysine, creatinine, lactate, $\beta$-hydroxybutyrate, $\beta$-alanine, O-acetyl glycoprotein, N-acetyl glycoprotein, glucose, glutamate, citrate, adipic acid, arginino-succinate, 2-aminoadipate, $\mathrm{N}$-acetyl citrulline.

Therefore, metabolic pathway about puromycin amino-nucleoside, uranyl nitrate and bromoethanamin on liver and kidney can finally show how stack plot of NMR spectra meaning characteristic metabolic fingerprints of tissue-specific toxicity produced by different site-selective xenobiotics given in single doses to rats in relation to an untreated control. And then, it shows the xenobiotics affect specific regions within the organs and give the stress to specific organ selectively. 


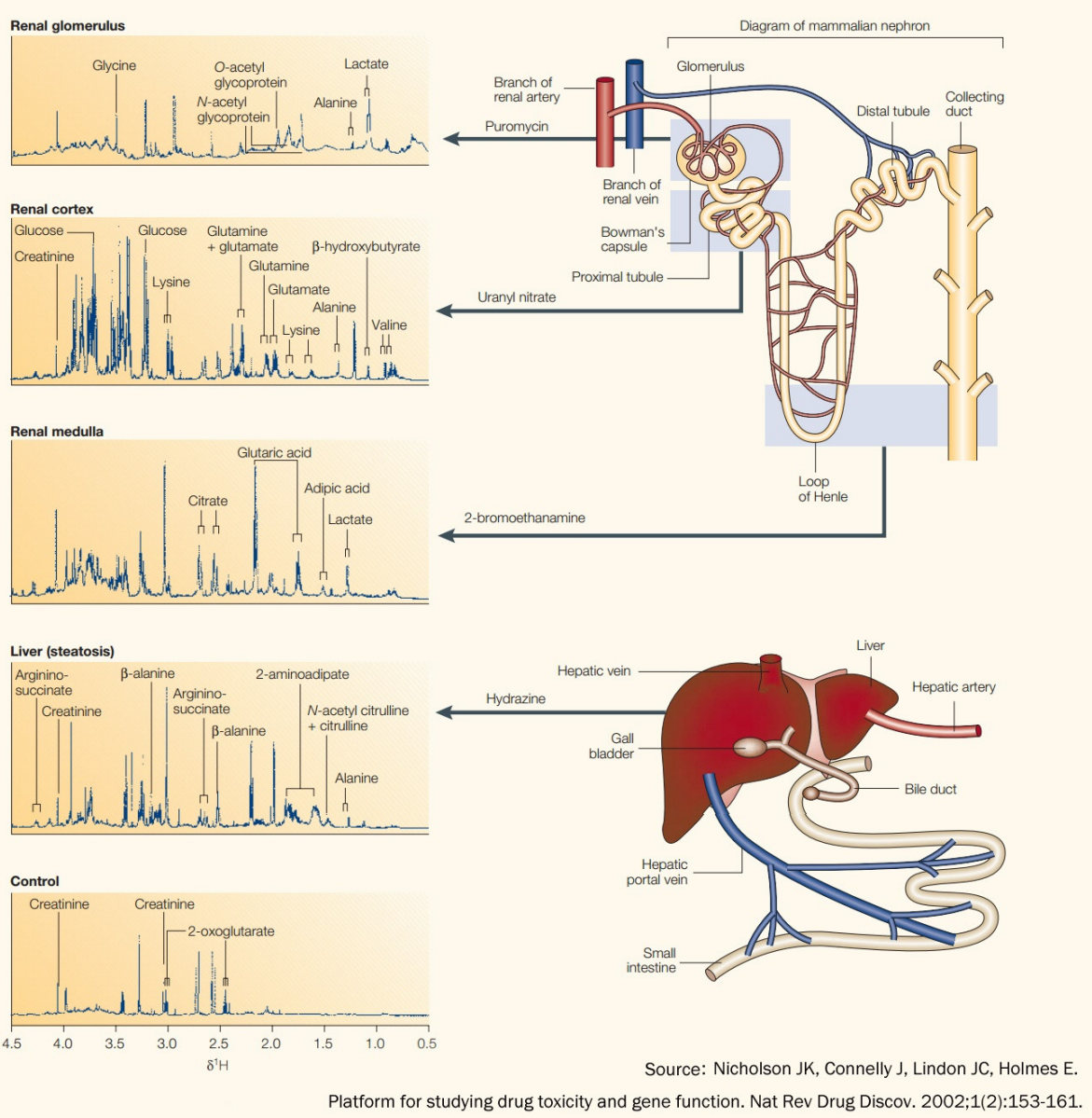

Figure 2. Chemical compound tracking to each metabolic pathway by using the NMR.

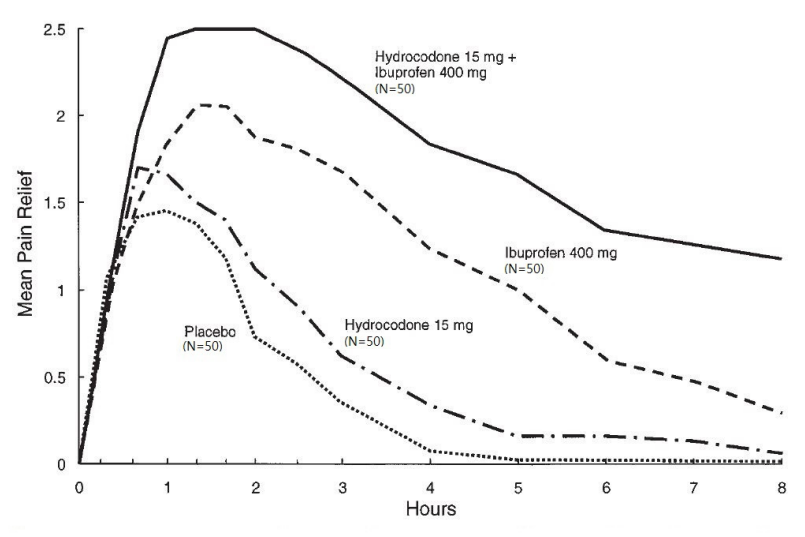

Source: Wideman GL, Keffer M, Morris E, Doyle RT, Jiang JG, Beaver WT, et al. Analgesic efficacy of

Figure 3. Combination of hydrocodone with ibuprofen in postoperative pain.

According to a previous research (Figure 3) [7], it can show how drug combination effectively work than the single pain relief. Because drugs combination can comprehensively try and stimulate various pathways to treat the pain. On the other hand, if a couple of drugs which have same metabolic pathway are used to treat the pain at one time, vascular events will significantly occur in the each organ which is included in the drug's metabolic pathway [8]. Therefore, in case of patient who has taking a number of NSAIDs, the medical provider have to avoid to prescribe similar drugs to patient for a long term. So that cell of patient's organ can selectively be prevented from necrosis and toxicity. According to previous study about hydrocodone with ibuprofen [7], it can show analgesic combination can be much effective than single analgesic. Basically, the (Figure 4) shows green arrow shows a normal mucosal cell. Blue arrow shows mucosal cell get a damage when treated with Ibuprofen. Black arrow represents the mucosal cell get a damage (ulcer) in high resolution $(\times 40)$ [2]. So, the best way to avoid damage on tissue is using the safe drug. But if cannot, patients and profession each other have to choose pain reliefs selec- 

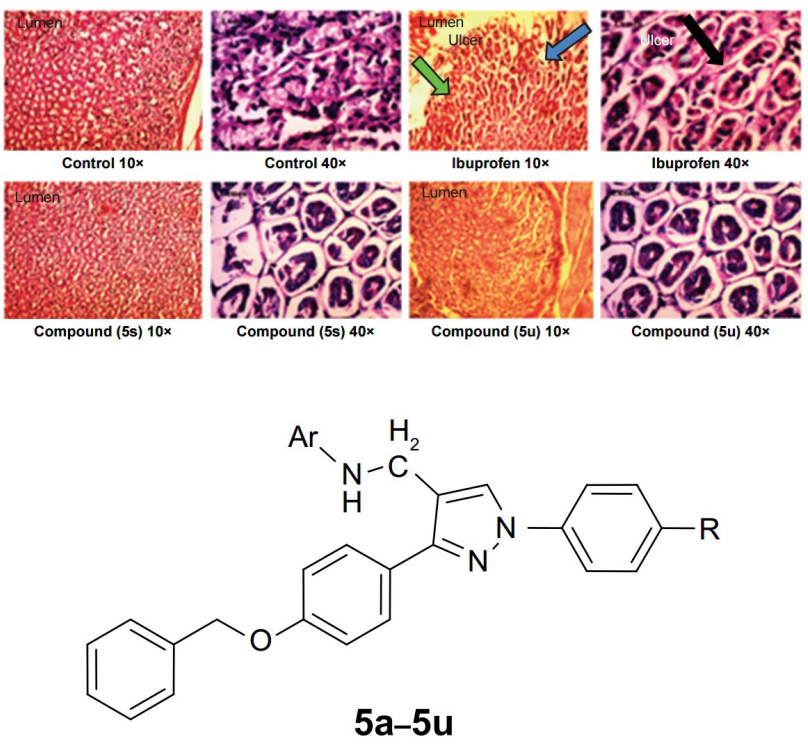

Source: Alam MJ, Alam O, Khan SA, Naim MJ, Islamuddin M, Deora GS. Drug Des Dev Ther. 2016;10:3529-3543.

Figure 4. Molecular docking and prevention side effect of NSAID by using the similar and designed NSAID.

tively to avoid each toxicity. According to (Figure 4), it shows designed NSAID (Non steroidal anti inflammatory drug) (eg. $5 \mathrm{~s}-5 \mathrm{u}$ ) which came from pyrazole analogue which is basic structure of certain NSAIDs such as celecoxib, deracoxib, lonazolac, antipyrine, metamizole, SC558, SC560, SC581 [2]. And these similar NSAIDs compounds are including 5s (Ar : 2-chlorophenyl with following structure in (Figure 2) and $5 \mathrm{u}$ (Ar : 4-Methylphenyl with following structure in (Figure 4). As it's known well, the ibuprofen resulted in damage or ulceration to the epithelial layer of stomachs of experimental rats [2]. On the other hand, both $5 \mathrm{~s}$, $5 \mathrm{u}$ in (Figure 4) didn't appear damage or ulceration [2]. These things are indirectly showing that each chemical metabolism rarely overlap each over. Therefore, it's experimentally proved that each pain reliefs possibly can be used to treat musculoskeletal pain by its own mechanism each. Furthermore, not only pain reliefs but also stretches as rehabilitation can be used to treat musculoskeletal pain avoiding overdose of pain reliefs in case of this combination such as robaxacet, robax platinum what we used in this study.

\section{DISCUSSION}

In patients with rheumatoid arthritis, treatment with rofecoxib, a selective inhibitor of cyclooxygenase-2, is associated with significantly fewer clinically important upper gastrointestinal events than treatment with naproxen, a nonselective inhibitor [26,27]. Because methocarbamol may possess a general CNS-depressant effect, patients should be cautioned about combined effects with alcohol and other CNS depressants [23]. Patients should be cautioned that methocarbamol may cause drowsiness or dizziness, which may impair their ability to operate motor vehicles or machinery. Methocarbamol may inhibit the effect of pyridostigmine bromide [23]. Therefore, methocarbamol should be used with caution in patients with myasthenia gravis receiving anticholinesterase agents [9]. Also, methocarbamol may cause a color interference in certain screening tests for 5-hydroxyindoleacetic acid (5-HIAA) using nitrosonaphthol reagent and in screening tests for urinary vanillylmandelic acid (VMA) using the gitlow method [27]. In other words, researchers who try to track the certain metabolism pathway of specific medication can use various methods. By using various methods such as nucleic magnetic resonance, isotope tracking on certain compound, blood or urine test and any others. As we previously mentioned, every drug has differing degrees of possible toxicity that must be considered in context. For example, depending on the situation, some toxicity can be beneficial. For instance, alkylating agents, nitrogen mustards, alkyl sulfonates, ethylenimines, nitrosoureas and triazines may be beneficial in chemotherapy according to research of Bjarnason I and Takeuchi K [26]. Therefore, the health professional must take into account the patient's symptoms, underlying disease and goals of treatment in order to effectively control and limit toxicity to acceptable thresholds and achieve maximum benefit [27] .

Even though we are facing a limit to track all kinds of NSAIDs in the world, it is necessary to study metabolic circuits that prevent organ damage by more various drug tracking methods such as further NMR, isotopes and any 
other ways to track. For example, we can refer xenobiotic to describe prevention hepatotoxicity and other toxicity from overdose. In case of xenobiotic, it's telling that artificial compound such as pain relief which comes from out of natural environment can't easily be adapted as well as natural substance to human body. Because the human body has been adapted with natural substances, natural food and a number of specific chemical receptors which have been adapted to a natural organism as well each other. Not only artificial compounds such as pain reliefs but also antibiotics are also xenobiotic because the human body does not produce them itself, nor are they part of a normal food according to research of Mansuy D [28].

Therefore, we tried to make the combined way to treat musculoskeletal pain by using alternative prescription such as stretch to prevent toxicity from xenobiotic such as artificial compound. Stretch and exercise instead of pain relief used to be alternative against any other treatment for pain. Especially, exercise is also used as a part of homeostasis of human body [29]. As a result, we can describe this study is kind of combined xenobiotic and homeostasis. Homeostasis of human body can result after induced eccentric and concentric muscle training. Participation in eccentric training and conditioning, including resistance training and activities that emphasize eccentric lengthening of the muscle including downhill running on a moderate to high incline can result in considerable soreness within 24 to 48 hours, even though blood lactate levels, previously thought to cause muscle soreness, were much higher with level running [29].

Therefore, combined prescription including pain reliefs and invasive stretch including no more dedication can be proper treatment for musculoskeletal pain and toxicity because the stretch makes muscle cells get released from inflammation as well without overdose. In other words, the drug combination of the methocarbamol $500 \mathrm{mg}$, acetaminophen $325 \mathrm{mg}$ and ibuprofen $200 \mathrm{mg}$ tablets yielded the similar benefits as the methocarbamol $500 \mathrm{mg}$ and acetaminophen $325 \mathrm{mg}$ tablets paired with physical stretching exercises in regards to overall pain control. Thus, a selective combination of pain management drugs can be utilized in order to help avoid adverse effects and toxicities according to a specific patient's underlying co-morbid cardiovascular, gastrointestinal, or other medical history that may be concerning for pain relief medication use. There is especially a need for such studies for patients such as professional athletes and soldiers exposed to the risk of chronic musculoskeletal diseases constantly to prevent various type of overdose from toxicity.

\section{요 약}

비 스테로이드성 항염증제에 대한 개별적 독성증상을 예방 하기 위해 로박스 플라티넘(Robax Platinum), 로박스아세트 (Robaxacet), 나프록센(Naproxen) 그리고 재활치료를 선택적 으로 처방하여 비 스테로이드 진통소염제(Non-Steroidal Anti-Inflammatory Drugs)에 대한 독성증상을 예방을 위한 효 과 비교 연구를 진행하였다. 이 연구에서는 로박스 플라티넘 (Robax platinum), 로박스아세트(Robaxacet), 나프록센 (Naproxen)을 주한미군 처방전(Annex A-Over-The-Counter Prescription)을 기준으로 하여 처방하였고, 앨리스 리치의 통 증 척도(Alice Rich's Pain Scale)를 사용하여 통증 경과를 비교 하고 그 결과를 IBM SPSS statics 24 버전을 사용하여 데이터를 계산했다. 결합된 메토카바몰(Methocarbamol, $500 \mathrm{mg}$ ), 아 세트아미노펜(Acetaminophen, $325 \mathrm{mg}$ ), 이부프로펜(Ibuprofen, $200 \mathrm{mg}$ ) 정제는 결합된 메토카바몰(Methocarbamol, $500 \mathrm{mg}$ ) 정제와 함께 사용할 수 있다. 아세트아미노펜 (Acetaminophen, $325 \mathrm{mg}$ )의 알약이 통증을 조절하는 방법으로 사 용되었다. 메도카바몰 $500 \mathrm{mg}$, 아세트아미토펜 $325 \mathrm{mg}$ 및 이 부프로펜 $200 \mathrm{mg}$ 정제의 약물 조합은 메도카바몰 $500 \mathrm{mg}$ 및 아세트아미노펜 $325 \mathrm{mg}$ 정제가 전반적인 통증 조절과 관련하 여 물리적인 스트레칭 운동과 쌍을 이룬 것과 유사한 통증 완화 효과를 나타내었다.

Acknowledgements: We're grateful for dedication of service members of Republic of Korea and United States Forces.

Funding: None

Conflict of interest: None 


\section{REFERENCES}

1. Nicholson JK, Connelly J, Lindon JC, Holmes E. Platform for studying drug toxicity and gene function. Nat Rev Drug Discov. 2002;1(2):153-161.

2. Alam MJ, Alam O, Khan SA, Naim MJ, Islamuddin M, Deora GS. Synthesis, anti-inflammatory, analgesic, COX1/2-inhibitory activity, and molecular docking studies of hybrid pyrazole analogues. Drug Des Dev Ther. 2016;10:3529-3543.

3. Jung JY, Park MH, Park HJ, Shim SB, Cho YH, Kim JH, et al. Hydrogen NMR-based metabolic profiling of naproxen-induced toxicity in rats. Toxicology Letters, 2011;200(1):1-7.

4. Sanwal V, Pandya M, Bhaskaran M, Franki N, Reddy K, Ding G, et al. Puromycin aminonucleoside induces glomerular epithelial cell apoptosis. Exp Mol Pathol. 2001;70(1):54-64.

5. Flamenbaum W. Uranyl nitrate-induced acute renal failure in the rat: Micropuncture and renal hemodynamic studies. Kidney Int Rep. 1974;6(6):408-418.

6. Peter HY, Davisa BA, Denga Y. 2-Bromoethylamine as a potent selective suicide inhibitor for semicarbazide-sensitive amine oxidase. Biochem Pharm. 2001;61(6):741-748.

7. Wideman GL, Keffer M, Morris E, Doyle RT, Jiang JG, Beaver WT, et al. Analgesic efficacy of a combination of hydrocodone with ibuprofen in postoperative pain. CPT Pharmacometrics Syst Pharmacol. 1999;65(1):66-76.

8. Lucile Packard Children's Hospital Heart Center. 0 - 10 Comparative pain scale [Internet]. Standford: Palo alto; 2016 [cited 2016 May 14]. Available from: https://lane.stanford.edu/ portals/cvicu/HCP_Neuro_Tab_4/0-

9. Bruce RB, Turnbull LB, Newman JH. Metabolism of methocarbamol in the rat, dog, and human. J Pharm Sci. 1971; 60(1):104-106.

10. Prescott, LF. Paracetamol (acetaminophen). 1st ed. Boca Raton: CRC press; 1996. p140-156.

11. Fortuny J, Kogevinas M, Garciaclosas M. Real FX, Tardòn A, Garciaclosas R, et al. Use of Analgesics and Nonsteroidal Anti-inflammatory Drugs, Genetic Predisposition, and Bladder Cancer Risk in Spain. Cancer Epidemiology. 2006;15(9):16961702.

12. Hamman MA, Thompson GA, Hall SD, Regioselective and stereoselective metabolism of ibuprofen by human cytochrome P450 2C. Biochem Pharmacol. 1997;54(1):33-41.

13. Neunzig I, Göhring A, Drăgan CA, Zapp J, Peters FT, Maurer HH, et al. Production and NMR analysis of the human ibuprofen metabolite 3-hydroxyibuprofen. J Biotechnol. 2012;157(3): 417-420.

14. Davies NM. Clinical pharmacokinetics of ibuprofen. The first 30 years. Clin Pharmacokinet. 1998;34(2):101-154.

15. Dahlin DC, Miwa GT, Lu AY, Nelson SD. N-acetyl-p-benzoquinone imine: a cytochrome P-450-mediated oxidation product of acetaminophen. Proc Natl Acad Sci. 1984;81(5):1327-1331.

16. Dong H, Haining RL, Thummel KE, Rettie AE, Nelson SD. Involvement of human cytochrome P450 2D6 in the bioactivation of acetaminophen. Drug Metab Dispos. 2000; 28(12): 1397-1400.

17. Raucy JL, Lasker JM, Lieber CS, Black M. Acetaminophen activation by human liver cytochromes P450IIE1 and P450IA2. Arch Biochemd Biophys. 1989;271(2):270-283.

18. Jollow DJ, Mitchell JR, Potter WZ, Davis DC, Gillette JR, Brodie BB. Acetaminophen-induced hepatic necrosis. II. Role of $\mathrm{co}^{-}$ valent binding in vivo. J Pharmacol Exp. 1973;187(1):195-202.

19. Lai MW, Klein-Schwartz W, Rodger GC, Abrams JY, Haber DA, Bronstein AC, et al. 2005 Annual Report of the American Association of Poison Control Centers' National Poisoning and Exposure. Cli Toxic, 2006;44:803-932.

20. Drug dot com. Acetaminophen dosage [Internet]. Washington DC: Cerner Multum; 2016 [cited 2016 May 10]. Available from: https://www.drugs.com/dosage/acetaminophen.html.

21. Drug dot com. Naproxen dosage [Internet]. Washington DC: Cerner Multum; 2016 [cited 2016 May 10]. Available from: https://www.drugs.com/dosage/naproxen.html.

22. Thomas ED. Exercise in the Management of Chronic Back Pain. Ochsner J. 2014; 14(1):101-107.

23. Drug dot com. Methocarbamol dosage [Internet]. Washington DC: Cerner Multum; 2016 [cited 2016 May 10]. Available from: https://www.drugs.com/pro/methocarbamol.html.

24. Hinson JA, Roberts DW, Benson RW, Dalhoff K, Loft S, Poulsen HE. Mechanism of paracetamol toxicity. Lancet. 1990;335 (8691):732.

25. Kearney PM, Baigent C, Godwin J, Halls H, Emberson JR, Patrono C. Do selective cyclo-oxygenase- 2 inhibitors and traditional non-steroidal anti-inflammatory drugs increase the risk of atherothrombosis. Meta-analysis of randomised trials. BMJ. 2006;332(7553):1302-1308.

26. Bjarnason I, Takeuchi K. Intestinal permeability in the pathogenesis of NSAID-induced enteropathy. J Gastroenterol. 2009;44(19):23-29.

27. Bombardier C, Laine L, Reicin A, Shapiro D, Burgos-Vargas R, Davis B, et al. Comparison of upper gastrointestinal toxicity of rofecoxib and naproxen in patients with rheumatoid arthritis. N Engl J Med. 2000;343:1520-1528.

28. Mansuy D. Metabolism of xenobiotics with beneficial and adverse effects. Biol Aujourdhui. 2013;207(1):33-37.

29. Kenney WL, Wilmore J, Costill D. Physiology of sport and exercise. 6th ed. Champaign: Human kinetics; 2015. p213-218. 